\title{
Immune reconstitution inflammatory syndrome from Penicillium marneffei in an HIV-infected child: a case report and review of literature
}

\author{
Tavitiya Sudjaritruk', Thira Sirisanthana ${ }^{2}$ and Virat Sirisanthana ${ }^{1,2^{*}}$
}

\begin{abstract}
Backgrounds: Disseminated Penicillium marneffei infection is one of the most common HIV-related opportunistic infections in Southeast Asia. Immune reconstitution inflammatory syndrome (IRIS) is a complication related to antiretroviral therapy (ART)-induced immune restoration. The aim of this report is to present a case of HIV-infected child who developed an unmasking type of IRIS caused by disseminated P. marneffei infection after ART initiation.

Case presentation: A 14-year-old Thai HIV-infected girl presented with high-grade fever, multiple painful ulcerated oral lesions, generalized non-pruritic erythrematous skin papules and nodules with central umbilication, and multiple swollen, warm, and tender joints 8 weeks after ART initiation. At that time, her CD4 $4^{+}$cell count was $7.2 \%$ or 39 cells $/ \mathrm{mm}^{3}$. On admission, her repeated $\mathrm{CD}^{+}$cell count was $11 \%$ or 51 cells $/ \mathrm{mm}^{3}$ and her plasma HIV-RNA level was $<50$ copies/mL. Her skin biopsy showed necrotizing histiocytic granuloma formation with neutrophilic infiltration in the upper and reticular dermis. Tissue sections stained with hematoxylin and eosin (H\&E), periodic acid-Schiff (PAS), and Grocott methenamine silver (GMS) stain revealed numerous intracellular and extracellular, round to oval, elongated, thin-walled yeast cells with central septation. The hemoculture, bone marrow culture, and skin culture revealed no growth of fungus or bacteria. Our patient responded well to intravenous amphotericin B followed by oral itraconazole. She fully recovered after 4-month antifungal treatment without evidence of recurrence of disease.
\end{abstract}

Conclusions: IRIS from P. marneffei in HIV-infected people is rare. Appropriate recognition and properly treatment is important for a good prognosis.

\section{Background}

Penicillium marneffei is a dimorphic fungus which can cause a fatal systemic mycosis in human immunodeficiency virus (HIV)-infected patients. This organism is endemic in tropical Asia, especially Thailand, northeastern India, China, Hong Kong, Vietnam, and Taiwan [1-6]. Disseminated P. marneffei infection is one of the most common HIV-related opportunistic infections in northern Thailand [5]. The typical manifestations of $P$. marneffei infection in HIV-infected individuals include fever, anemia, weight loss, skin lesions, generalized lymphadenopathy, and hepatomegaly [5,7]. The primary treatment with amphotericin B and itraconazole and

\footnotetext{
* Correspondence: vsirisan@med.cmu.ac.th

'Division of Infectious Diseases, Department of Pediatrics, Faculty of

Medicine, Chiang Mai University, 50200 Chiang Mai, Thailand

Full list of author information is available at the end of the article
}

secondary prophylaxis with itraconazole are very effective regimens [8]. Patients who do not receive timely and appropriate antifungal treatment have poor outcomes [5]. Immune reconstitution inflammatory syndrome (IRIS) is a complication related to antiretroviral therapy (ART)-induced immune restoration. IRIS manifests as a paradoxical exacerbation of previously treated opportunistic infections (paradoxical or worsening IRIS) or as an unmasking of subclinical, untreated infections (unmasking IRIS) [9-12]. It is a consequence of exaggerated activation of the immune response against infectious organisms $[13,14]$. In this report, we present a case of HIV-infected child with IRIS from disseminated P. marneffei infection. 


\section{Case presentation}

A 14-year-old Thai girl presented at a provincial hospital with fever, oral ulcers, disseminated papular lesions and multiple joint pain for 4 weeks. Twelve weeks before this admission, she was diagnosed as a case of perinatal HIV infection after presenting with disseminated herpes zoster infection and Pneumocystis jirovecii pneumonia (PJP). At that time, her $\mathrm{CD} 4^{+}$cell count was $7.2 \%$ or 39 cells $/ \mathrm{mm}^{3}$. Plasma HIV-RNA level was not obtained. She was started on GPOvirS30 ${ }^{\circledR}$ (a fixed drug combination of stavudine $30 \mathrm{mg}$, lamivudine $150 \mathrm{mg}$ and nevirapine $200 \mathrm{mg}$ ) 1 tablet twice daily and PJP prophylaxis with trimethoprim-sulfamethoxazole. Eight weeks after starting ART she developed fever, multiple oral ulcers, disseminated papular lesions over the face, body, and extremities, and severe pain in many joints. The symptoms did not respond to many kinds of oral antibiotics and she was referred to Chiang Mai University (CMU) Hospital.

Upon admission to CMU Hospital, the physical examination revealed high-grade fever. Multiple painful ulcerated lesions were found on the lip and oral mucosa. Generalized non-pruritic erythrematous papules and nodules with central umbilication were found over the face, body, and extremities (Figure 1). Marked swelling, warmth, and tenderness of many joints, including right shoulder, wrist, metacarpophalangeal, knee, and ankle joints were also noticed. Neither lymphadenopathy nor hepatosplenomegaly were found. Her laboratory results are shown in Table $1 . \mathrm{CD}^{+}$cell count was $11 \%$ or 51 cells $/ \mathrm{mm}^{3}$. Plasma HIV-RNA level was $<50$ copies $/ \mathrm{mL}$. Chest roentgenogram was normal. Roentgenograms of both wrists and ankles showed multiple round radiolucent defects of the bones (Figure 2). Skin biopsy showed necrotizing histiocytic granuloma formation with

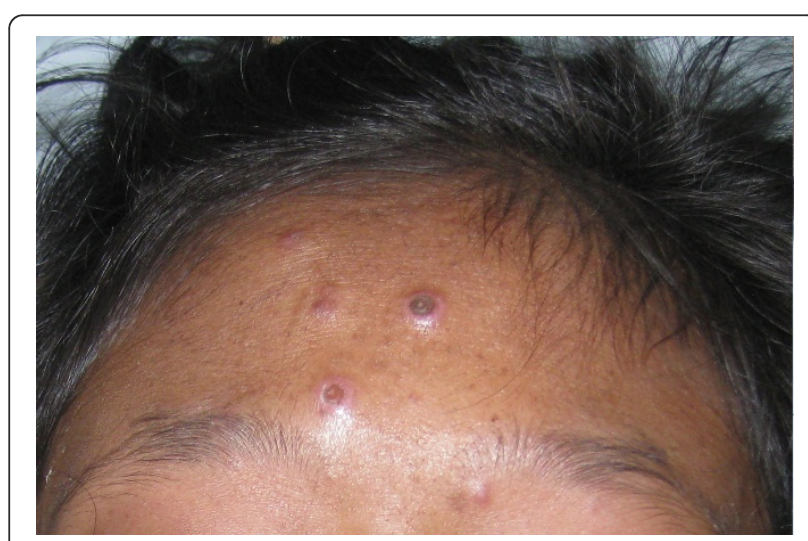

Figure 1 Cutaneous lesions initially presented as small papules, enlarged to larger papules with central necrotic umbilications. They were predominantly found on the face and extremities.
Table 1 Laboratory results on the day of admission

\begin{tabular}{ccc}
\hline Laboratory investigations & Results & Normal value \\
\hline Hemoglobin $(\mathrm{g} / \mathrm{dL})$ & 8.0 & $10.0-15.0$ \\
\hline Hematocrit $(\%)$ & 23.9 & $36.0-45.0$ \\
\hline White blood count $\left(\times 10^{9} / \mathrm{L}\right)$ & 7.6 & $5-10$ \\
\hline Absolute neutrophil count & 5.9 & $2.0-8.0$ \\
\hline Absolute lymphocyte count & 0.5 & $0.7-4.4$ \\
\hline Platelet $\left(\times 10^{9} / \mathrm{L}\right)$ & 498 & $100-400$ \\
\hline $\mathrm{SGOT}(\mathrm{U} / \mathrm{L})$ & 21 & $<35$ \\
\hline $\mathrm{SGPT}(\mathrm{U} / \mathrm{L})$ & 10 & $<41$ \\
\hline $\mathrm{LDH}(\mathrm{U} / \mathrm{L})$ & 161 & $120-450$ \\
\hline ESR $(\mathrm{mm} / \mathrm{hr})$ & $>140$ & $0-10$ \\
\hline $\mathrm{CRP}(\mathrm{mg} / \mathrm{L})$ & 80.7 & $0-5.0$
\end{tabular}

Note: SGOT indicates Serum glutamic oxaloacetic transaminase; SGPT, Serum glutamic pyruvic transaminase; LDH, Lactate dehydrogenase; ESR, Erythrocyte sedimentation rate; $\mathrm{CRP}, \mathrm{C}$-reactive protein

neutrophilic infiltration in the upper and reticular dermis. Tissue sections from skin biopsy stained with hematoxylin and eosin (H\&E), periodic acid-Schiff (PAS), and Grocott methenamine silver (GMS) stain revealed numerous intracellular and extracellular, round to oval, elongated, thin-walled yeast cells with central septation (Figure 3). No organism was observed in the bone marrow aspirate specimen. The hemoculture, bone marrow culture, and skin culture revealed no evidence of $P$. marneffei or other fungus. Blood was also sent for mycobacterial culture with negative results. Serum cryptococcal antigen was negative. The diagnosis of disseminated P. marneffei infection from unmasking IRIS was made.

The patient was treated with intravenous amphotericin $B$ at a dosage of $0.7 \mathrm{mg} / \mathrm{kg}$ for 2 weeks along with paracetamol and ibuprofen, followed by oral itraconazole at a dosage of $5 \mathrm{mg} / \mathrm{kg}$ twice daily orally. She responded well to treatment. Her fever, skin lesions, and joints pain gradually resolved. She was discharged with a plan to complete a 10-week course of oral itraconazole therapy followed by the maintenance therapy with oral itraconazole at a reduced dosage of $5 \mathrm{mg} / \mathrm{kg}$ daily. Her skin lesions and joints pain resolved after 4 weeks of antifungal treatment, and itraconazole was discontinued after 4 months of maintenance treatment. After 1 year of therapy, she had gained $4 \mathrm{~kg}$ weight without recurrence of P. marneffei infection. Her repeated $\mathrm{CD}^{+}{ }^{+}$cell count had risen to $21.1 \%$ or 269 cells $/ \mathrm{mm}^{3}$. Her plasma HIV RNA level was undetectable $(<50$ copies $/ \mathrm{mL})$.

\section{Conclusions}

We reported a case of HIV-infected child who developed an unmasking IRIS caused by disseminated $P$. marneffei infection 8 weeks after ART initiation. After treatment with antifungal therapy, amphotericin B 


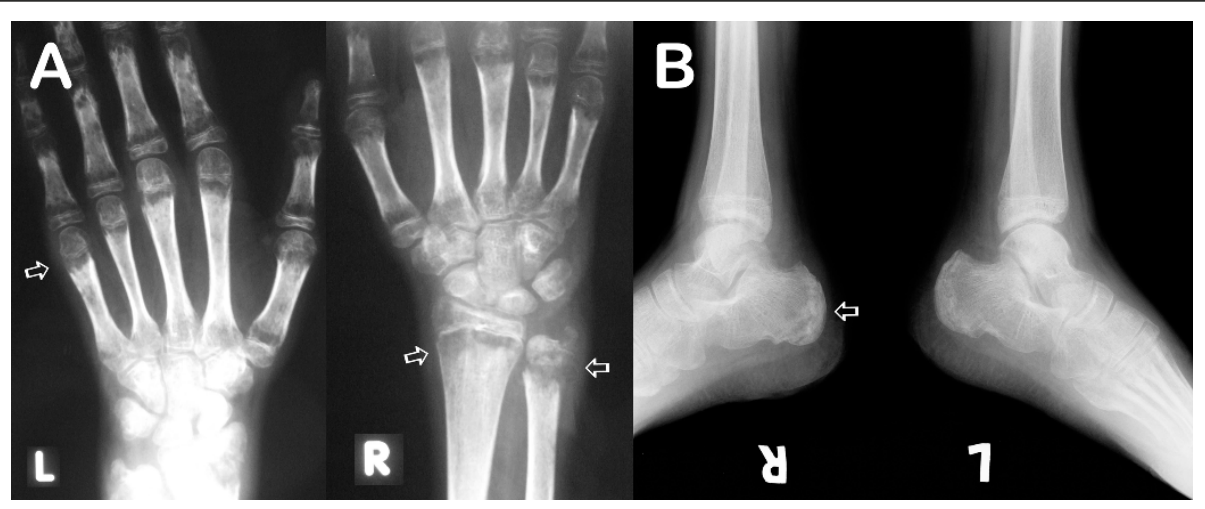

Figure 2 Radiologic evidences of osteolytic lesions of the extremities. a. Multiple osteolytic lesions are noted along the metaphyseal line of the 2nd to 4th metacarpophalangeal joints (arrow) with pericarticular osteopenia of the wrist and metacarpophalangeal joints. Large osteolytic lesions are also noted at right distal radius and ulnar (arrows). No widening of both wrist joint spaces. Sharp bony cortex of both radius and ulnar. b. Multiple osteolytic lesions are noted at right calcaneous (arrow). No widening of both ankle joint spaces. Sharp bony cortex of both tibia and fibula.

followed by itraconazole, she had fully recovery without evidence of recurrence.

IRIS is a manifestation of vigorous immune recovery which usually occurs within a few weeks to months after potent ART initiation in advanced stage HIVinfected patients. This inflammatory reaction is directed against pathogens causing latent or subclinical infection. The majority of patients present with unusual manifestations of opportunistic infections, most often while the number of $\mathrm{CD}_{4}^{+}$cell count is increasing and/or the plasma HIV RNA level is decreasing $[11,12,15,16]$. This syndrome can be severe, and results in significant morbidity and occasional mortality. The information about incidence and spectrum of IRIS in HIV-infected children was limited. Puthanakit et al. reported an incidence of
$19 \%$ of IRIS in advanced stage Thai HIV-infected children with the median onset of 4 weeks (range, 2-31) after ART commencement. The three major causative pathogens were mycobacterial spp. (43.8\%), both Mycobacterium tuberculosis (TB) and non-tuberculous mycobacterium, varicella zoster virus (VZV) (21.9\%), and herpes simplex virus (HSV) (21.9\%) [17]. Recently, Smith et al. reported an incidence of $21 \%$ of IRIS in South African HIV-infected children at a median of 16 days (range, 7-115 days) post-ART initiation. Bacillus Calmette-Guérin reaction (71\%) and TB (35.3\%) were the most common conditions in their children [18]. Similarly, Wang et al. reported an incidence of $20 \%$ of IRIS (19.8 events per 100 person years) in HIV-infected children in Peru with 6.6 weeks (range, 2-32) median

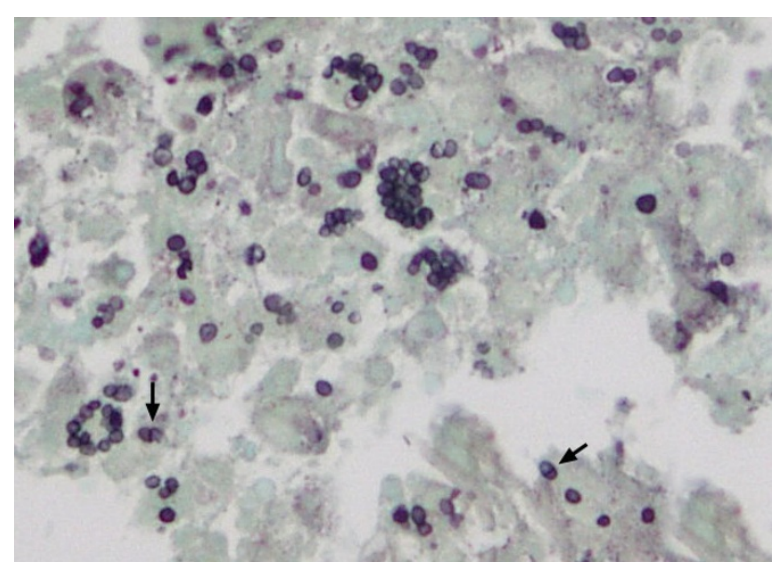

Figure 3 Photomicrograph of Penicillium marneffei (courtesy of Kornkanok Sukapan) in the skin lesion section stained with Grocott Methenamine Silver. Numerous intracellular and extracellular, round to oval, elongated, thin-walled yeast-like organisms. The characteristic transverse septum (arrows) within the yeast cell is seen. Magnification, $\times 1000$. 
time to IRIS. The most common IRIS events were VZV infection (33.3\%), HSV labialis (33.3\%), and TB infection (22.2\%) [19].

Our patient developed symptoms 8 weeks after the initiation of ART, which is a common period for IRIS development. They included fever, multiple painful oral ulcers, disseminated umbilicated papular skin lesions over the face, body and extremities, and multiple swollen, warm, and tender joints which are typical clinical presentations of disseminated $P$. marneffei infection. Tissue sections of the skin biopsy stained with H\&E, PAS, and GMS revealed numerous yeast cells of P. marneffei, but culture did not yield the organism These signs and symptoms, especially prominent inflammatory articular manifestations, and an excessive inflammation reaction in histopathology of the skin biopsyspecimen demonstrated vigorous immune recovery which acted on unviable $P$. marneffei antigens. Improvement of her immune response was also evidenced by her rising $\mathrm{CD} 4^{+}$cell count and undetectable plasma HIV RNA level. The improved immune response had unmasked a previously quiescent $P$. marneffei infection causing the patient's symptoms.

P. marneffei is an important causative organism of opportunistic infection in immunocompromised people, particularly HIV-infected persons who live in or travel to Southeast Asia $[4-7,20]$. By reviewing the English medical literature, $P$. marneffei had been reported as a causative organism of IRIS in only 4 HIV-infected patients. The first case was reported in 2007 from India [21]. Since then, there have been 2 additional cases reported from the Indian subcontinent [22,23], and 1 case from United Kingdom who had traveled to Thailand [24]. Case histories and the characteristics of these 4 cases are summarized in Table 2. All patients lived in or traveled to an endemic area of P. marneffei. Similar with our patient, all except one case (case 1) had evidences of immune recovery during IRIS presentation which occurred within 2-4 weeks after ART initiation. Both kinds of IRIS presentations were reported, 3 as unmasking, and 1 as paradoxical types. All except 1 patient (case 1) had generalized skin and/or mucocutaneous lesions which are the common clinical characteristics of $P$. marneffei infection. The common presenting symptoms were generalized skin and/or mucocutaneous lesions, pyrexia, lymphadenopathy, hepatomegaly and splenomegaly. Our patient also had osteoarticular involvement by clinical and/or radiological findings, similar to case 2 in Table 2. The osteomyelitis was seen in multiple including flat bones, long bones of the extremities and the small bones of hands and feet. The arthritis could involve both large peripheral joints and small joints of the fingers [20,25-27]. These findings were similar to those observed in tuberculosis and systemic mycoses other than penicilliosis [28].

Diagnosis of infection by $P$. marneffei is usually made by identifying the fungus in clinical specimens by microscopy and culture. In addition, P. marneffei can be seen in histopathological sections stained with H\&E, GMS, or PAS stain, which typically appears as unicellular round to oval yeast cells with transverse septum in macrophage or histiocyte [29]. This finding is unique to infection with $P$. marneffei. All 4 previously reported cases had evidences of the fungus in the clinical specimens, including blood, skin biopsies, and lymph node biopsies and culture [21-24]. However, in our reported case, we found the evidences of organism in histopathological sections with special stains but could not identify fungus by culture of the clinical specimens. This might be due to the fact that the organism was already killed by the immune system of the patient.

Treatment of disseminated $P$. marneffei infection is well described [30]. Intravenous amphotericin B for 2 weeks followed by oral itraconazole for 10 weeks is recommended. Although itraconazole maintenance treatment was shown to prevent relapse of penicilliosis when the patients had CD4 cell count of 100 cells/ $\mu \mathrm{l}$ or greater for at least 6 months after HAART [31], our patient who unintentionally discontinued maintenance treatment after 4-month therapy without knowing the CD4 cell count did not have relapse. Details of treatments and outcomes were available in 3 of 4 previously reported cases (Table $2)$. Two cases (case 1,4) were treated with intravenous amphotericin B for 2 weeks, followed by oral itraconazole for 10 weeks. The other case (case 3 ) received single dose of intravenous amphotericin B because the patient refused to stay in the hospital. Therefore, he was treated by only itraconazole orally for 8 weeks. All 3 cases were continued on maintenance treatment with oral itraconazole along with the ART. Their symptoms improved markedly after 2-10 months of the therapy.

In summary, IRIS is not a rare condition, especially in the ART era. IRIS caused by P. marneffei infection will be increasingly recognized in the endemic area of the fungus. It requires appropriate recognition and proper treatment. The clinicians' awareness is crucial to ensure a good prognosis.

\section{Consent}

Written informed consent was obtained from the parents of the patient for publication of this case report and any accompanying images. A copy of the written consent is available for review by the Editor-in-Chief of this journal.

\section{Funding}

None. 
Table 2 Immune reconstitution inflammatory syndrome with disseminated Penicillium marneffei infection in HIV-infected patients: Literature review

\begin{tabular}{|c|c|c|c|c|c|c|c|c|c|c|c|c|c|c|c|}
\hline \multirow[t]{2}{*}{ Case } & \multirow{2}{*}{$\begin{array}{l}\text { Country } \\
\text { reported } \\
\text { year }\end{array}$} & \multirow{2}{*}{$\begin{array}{l}\text { Age } \\
\text { (yr) }\end{array}$} & \multirow[t]{2}{*}{ Sex } & \multicolumn{3}{|c|}{ Status before ART commencement } & \multirow{2}{*}{$\begin{array}{l}\text { Type } \\
\text { of } \\
\text { ART }\end{array}$} & \multirow{2}{*}{$\begin{array}{l}\text { Type of } \\
\text { IRIS }\end{array}$} & \multirow{2}{*}{$\begin{array}{l}\text { Time } \\
\text { to } \\
\text { IRIS } \\
\text { onse }\end{array}$} & \multicolumn{3}{|c|}{ Status during IRIS presentation } & \multirow{2}{*}{$\begin{array}{l}\text { Method } \\
\text { for } \\
\text { diagnosis }\end{array}$} & \multirow[t]{2}{*}{ Treatments } & \multirow[t]{2}{*}{ Outcomes } \\
\hline & & & & Clinical symptoms & $\begin{array}{l}\text { CD4 } \\
\text { cell } \\
\text { count } \\
\text { (cells/ } \\
\left.\mathrm{mm}^{3}\right)\end{array}$ & $\begin{array}{l}\text { Viral } \\
\text { load } \\
\text { (copies/ } \\
\mathrm{mL} \text { ) }\end{array}$ & & & & Clinical symptoms & $\begin{array}{l}\text { CD4 } \\
\text { cell } \\
\text { count } \\
\text { (cells/ } \\
\mathrm{mm}^{3} \text { ) }\end{array}$ & $\begin{array}{l}\text { Viral } \\
\text { load } \\
\text { (copies/ } \\
\mathrm{mL} \text { ) }\end{array}$ & & & \\
\hline 1 & $\begin{array}{l}\text { India }{ }^{24} \\
2007\end{array}$ & 35 & M & $\begin{array}{l}\text { fever, loss of weight } \\
\text { and appetite, } \\
\text { hepatosplenomegaly, } \\
\text { herpes genitalis }\end{array}$ & 4 & NA & $\begin{array}{l}\mathrm{d} 4 \mathrm{~T}, \\
3 \mathrm{TC}, \\
\mathrm{NVP}\end{array}$ & unmasking & $\begin{array}{l}4 \\
\text { weeks }\end{array}$ & $\begin{array}{l}\text { afebrile, pallor, mild } \\
\text { icterus, cervical and } \\
\text { axillary } \\
\text { lymphadenopathy, } \\
\text { hepatosplenomegaly }\end{array}$ & NA & NA & $\begin{array}{l}\text { axillary LN } \\
\text { biopsy- } \\
\text { positive, } \\
\text { LN culture- } \\
\text { positive } \\
\text { blood } \\
\text { culture } \\
\text {-positive, }\end{array}$ & $\begin{array}{l}\text { AmphoB } 0.6 \text { MKD } \\
\text { for } 14 \text { days, } \\
\text { followed by } \\
\text { itraconazole } 400 \\
\text { mg/d for } 10 \text { wks, } \\
\text { then MT with } 200 \\
\text { mg/d }\end{array}$ & $\begin{array}{l}\text { At } 10 \text { mo; } 20 \\
\mathrm{~kg} \text { weight } \\
\text { gain, } \\
\text { decrease size } \\
\text { of } \mathrm{LN} \text {, liver, } \\
\text { spleen, CD4 } \\
=224 \text { cells/ } \\
\mathrm{mm}^{3}\end{array}$ \\
\hline 2 & $\begin{array}{l}\text { India } 25 \\
2009\end{array}$ & 12 & M & $\begin{array}{l}\text { fever, cough, weight } \\
\text { loss, diarrhea, } \\
\text { generalized papular } \\
\text { umbilicated lesion, } \\
\text { oral and esophageal } \\
\text { candidiasis }\end{array}$ & 11 & NA & $\begin{array}{l}\text { d4T, } \\
3 \mathrm{TC}, \\
\text { EFV }\end{array}$ & paradoxical & $\begin{array}{l}4 \\
\text { weeks }\end{array}$ & $\begin{array}{l}\text { fever, severe arthritis, } \\
\text { exacerbration of skin } \\
\text { lesions, generalised } \\
\text { lymphadenopathy }\end{array}$ & $\begin{array}{l}172 \\
\text { (wk 4) }\end{array}$ & NA & $\begin{array}{l}\text { blood } \\
\text { culture- } \\
\text { positive }\end{array}$ & NA & NA \\
\hline 3 & $\begin{array}{l}\text { India }{ }^{26}, \\
2010\end{array}$ & 28 & M & $\begin{array}{l}\text { fever, cough, loss of } \\
\text { weight, diarrhea, oral } \\
\text { candidiasis }\end{array}$ & 47 & NA & $\begin{array}{l}\text { d4T, } \\
3 T C_{1} \\
\text { NVP }\end{array}$ & unmasking & $\begin{array}{l}2 \\
\text { weeks }\end{array}$ & $\begin{array}{l}\text { multiple erythrematous, } \\
\text { scaly, papules and } \\
\text { nodules with central } \\
\text { necrosis on face } \\
\text { extremities, scortum }\end{array}$ & $\begin{array}{l}160 \\
\text { (wk 2) }\end{array}$ & NA & $\begin{array}{l}\text { skin } \\
\text { biopsy- } \\
\text { positive, } \\
\text { skin } \\
\text { culture- } \\
\text { positive, } \\
\text { blood } \\
\text { culture- } \\
\text { negative }\end{array}$ & $\begin{array}{l}\text { AmphoB } 0.6 \text { MKD } \\
\text { only } 1 \text { dose, then } \\
\text { itraconazole } 400 \\
\mathrm{mg} / \mathrm{d} \text { for } 2 \mathrm{mo}, \\
\text { then MT with } 200 \\
\mathrm{mg} / \mathrm{d}\end{array}$ & $\begin{array}{l}\text { At } 2 \text { mo; } 14 \\
\mathrm{~kg} \text { weight } \\
\text { gain, skin } \\
\text { lesions } \\
\text { disappear }\end{array}$ \\
\hline 4 & $\begin{array}{l}\text { UK } \\
\text { (traveled } \\
\text { to } \\
\text { Thailand) } \\
27,2010\end{array}$ & 39 & M & $\begin{array}{l}\text { fever, loss of weight } \\
\text { and appetite, PJP, } \\
\text { molluscum } \\
\text { contangiosum on } \\
\text { face }\end{array}$ & 72 & 38000000 & $\begin{array}{l}\text { TDF, } \\
\text { FTC, } \\
\text { EFV }\end{array}$ & unmasking & $\begin{array}{l}4 \\
\text { weeks }\end{array}$ & $\begin{array}{l}\text { multiple facial lesions, } \\
\text { disseminated non- } \\
\text { pruritic nodules, no } \\
\text { hepatosplenomegaly }\end{array}$ & $\begin{array}{l}273 \\
\text { (wk 8) }\end{array}$ & $\begin{array}{l}3 \text { log } \\
\text { drop } \\
\text { (wk 4) }\end{array}$ & $\begin{array}{l}\text { pus } \\
\text { culture- } \\
\text { positive }\end{array}$ & $\begin{array}{l}\text { AmphoB } 0.6 \text { MKD } \\
\text { for } 14 \text { days, } \\
\text { followed by } \\
\text { itraconazole } 600 \\
\mathrm{mg} / \mathrm{d} \text { for } 10 \text { wks, } \\
\text { then MT with } 200 \\
\mathrm{mg} / \mathrm{d}\end{array}$ & $\begin{array}{l}\text { At } 2 \text { mo; skin } \\
\text { lesions } \\
\text { regress At } 28 \\
\text { mo; CD4 }= \\
375 \text { cells/ } \\
\mathrm{mm}^{3}, \mathrm{VL}<50 \\
\text { copies } / \mathrm{mL}\end{array}$ \\
\hline 5 & $\begin{array}{l}\text { Thailand, } \\
2011 \\
\text { (Ours) }\end{array}$ & 14 & $\mathrm{~F}$ & $\begin{array}{l}\text { fever, loss of weight } \\
\text { and appetite, PJP, } \\
\text { herpes zoster on } \\
\text { trunk }\end{array}$ & 39 & NA & $\begin{array}{l}\mathrm{d} 4 \mathrm{~T}, \\
3 \mathrm{TC}, \\
\text { NVP }\end{array}$ & unmasking & $\begin{array}{l}8 \\
\text { weeks }\end{array}$ & $\begin{array}{l}\text { fever, severe } \\
\text { osteoarthritis, } \\
\text { disseminated non- } \\
\text { pruritic papules and } \\
\text { nodules with central } \\
\text { necrosis, oral ulcer, no } \\
\text { lymphadenopathy, no } \\
\text { hepatosplenomegaly }\end{array}$ & $\begin{array}{l}51 \\
\text { (wk 14) }\end{array}$ & $\begin{array}{l}<50 \\
(\text { wk 14) }\end{array}$ & $\begin{array}{l}\text { skin } \\
\text { biopsy- } \\
\text { positive, } \\
\text { skin } \\
\text { culture- } \\
\text { negative, } \\
\text { blood } \\
\text { culture- } \\
\text { negative }\end{array}$ & $\begin{array}{l}\text { AmphoB } 0.7 \text { MKD } \\
\text { for } 14 \text { days then } \\
\text { Itraconazole } 5 \text { MK } \\
\text { twice daily for } 10 \\
\text { weeks, then MT } \\
\text { with } 5 \text { MKD for } 4 \\
\text { months }\end{array}$ & $\begin{array}{l}\text { At } 12 \mathrm{mo} ; 4 \\
\mathrm{~kg} \text { weight } \\
\text { gain, CD4 }= \\
269 \text { cells/ } \\
\mathrm{mm}^{3}, \mathrm{VL}<50 \\
\text { copies } / \mathrm{mL}\end{array}$ \\
\hline
\end{tabular}




\section{Ethical approval}

This study was approved by Ethics Committee of Faculty of Medicine, Chiang Mai University, Chiang Mai, Thailand.

\begin{abstract}
Acknowledgements
The authors would like to thank Pannee Visrutaratna, Professor of Radiology, Department of Radiology, Faculty of Medicine, Chiang Mai University, Chiang Mai, Thailand for reviewing the radiological studies of this patient. The authors also thank Kornkanok Sukapan, Assistant Professor of Pathology, Department of Pathology, Faculty of Medicine, Chiang Mai University, Chiang Mai, Thailand for performing the organism identification. We wish to thank the National Research University Project (Chiang Mai University) under Thailand's Office of the Higher Education Commission for supporting the publication.

\section{Author details}

${ }^{1}$ Division of Infectious Diseases, Department of Pediatrics, Faculty of Medicine, Chiang Mai University, 50200 Chiang Mai, Thailand. ${ }^{2}$ Research Institute for Health Sciences, Chiang Mai University, Chiang Mai, Thailand.
\end{abstract}

\section{Authors' contributions}

All authors contributed to this work. TAS and VS were involved in the direct clinical care (diagnosis, decision making, and treatment) of the reported patient. Both provided the corresponding figures. All authors involved in the preparation of the manuscript. All authors read and approved the final version of the manuscript.

\section{Competing interests}

The authors declare that they have no competing interests.

Received: 10 May 2011 Accepted: 31 January 2012

Published: 31 January 2012

\section{References}

1. Chiang $C T$, Leu HS, Wu TL, Chan HL: Penicillium marneffei fungemia in an AIDS patient: the first case report in Taiwan. Changgeng Yi Xue Za Zhi 1998, 21:206-210.

2. Deng Z, Ribas JL, Gibson DW, Connor DH: Infections caused by Penicillium marneffei in China and Southeast Asia: review of eighteen published cases and report of four more Chinese cases. Rev Infect Dis 1988, 10:640-652.

3. Hien TV, Loc PP, Hoa NT, Duong NM, Quang VM, McNeil MM, et al: First cases of disseminated Penicilliosis marneffei infection among patients with acquired immunodeficiency syndrome in Vietnam. Clin Infect Dis 2001, 32:e78-80.

4. Ranjana KH, Priyokumar K, Singh TJ, Gupta ChC, Sharmila L, Singh PN, et al: Disseminated Penicillium marneffei infection among HIV-infected patients in Manipur state, India. J Infect 2002, 45:268-271.

5. Supparatpinyo K, Khamwan C, Baosoung V, Nelson KE, Sirisanthana T: Disseminated Penicillium marneffei infection in Southeast Asia. Lancet 1994, 344:110-113.

6. Wong KH, Lee SS, Chan KC, Choi T: Redefining AIDS: case exemplified by Penicillium marneffei infection in HIV-infected people in Hong Kong. Int J STD AIDS 1998, 9:555-556.

7. Vanittanakom N, Sirisanthana T: Penicillium marneffei infection in patients infected with human immunodeficiency virus. Curr Top Med Mycol 1997, 8:35-42.

8. Supparatpinyo K, Perriens J, Nelson KE, Sirisanthana T: A controlled trial of itraconazole to prevent relapse of Penicillium marneffei infection in patients infected with the human immunodeficiency virus. N Engl J Med 1998, 339:1739-1743.

9. Singh N: Perfect JR. Immune reconstitution syndrome associated with opportunistic mycoses. Lancet Infect Dis 2007, 7:395-401.

10. Lawn SD, Bekker LG, Miller RF: Immune reconstitution disease associated with mycobacterial infections in HIV-infected individuals receiving antiretrovirals. Lancet Infect Dis 2005, 5:361-373.

11. Shelburne SA, Hamill RJ, Rodriguez-Barradas MC, Greenberg SB, Atmar RL, Musher DW, et al: Immune reconstitution inflammatory syndrome: emergence of a unique syndrome during highly active antiretroviral therapy. Medicine 2002, 81:213-227.

12. French MA, Price $P$, Stone SF: Immune restoration disease after antiretroviral therapy. AIDS 2004, 18:1615-1627.

13. French MA: HIV/AIDS: immune reconstitution inflammatory syndrome: a reappraisal. Clin Infect Dis 2009, 48:101-107.

14. Boulware DR, Callens S, Pahwa S: Pediatric HIV immune reconstitution inflammatory syndrome. Curr Opin HIV AIDS 2008, 3:461-467.

15. Murdoch DM, Venter WD, Van RA, Feldman C: Immune reconstitution inflammatory syndrome (IRIS): review of common infectious manifestations and treatment options. AIDS Res Ther 2007, 4:9.

16. Hirsch HH, Kaufmann G, Sendi P, Battegay M: Immune reconstitution in HIV-infected patients. Clin Infect Dis 2004, 38:1159-1166.

17. Puthanakit $T$, Oberdorfer $P$, Akarathum N, Wannarit $P$, Sirisanthana $T$, Sirisanthana $V$ : Immune reconstitution syndrome after highly active antiretroviral therapy in HIV-infected Thai children. Pediatr Infect Dis J 2006, 25:53-58

18. Smith K, Kuhn L, Coovadia A, Meyers T, Hu CC, Reitz C, et al: Immune reconstitution inflammatory syndrome among HIV-infected South African infants initiating antiretroviral therapy. AIDS 2009, 23:1097-1107.

19. Wang ME, Castillo ME, Montano SM, Zunt JR: Immune reconstitution inflammatory syndrome in human immunodeficiency virus-infected children in Peru. Pediatr Infect Dis J 2009, 28:900-903.

20. Sirisanthana $V$, Sirisanthana T: Disseminated Penicillium marneffei infection in human immunodeficiency virus-infected children. Pediatr Infect Dis J 1995, 14:935-940.

21. Gupta S, Mathur P, Maskey D, Wig N, Singh S: Immune restoration syndrome with disseminated Penicillium marneffei and cytomegalovirus co-infections in an AIDS patient. AIDS Res Ther 2007, 4:21.

22. Saikia L, Nath R, Biswanath P, Hazarika D, Mahanta J: Penicillium marneffei infection in HIV infected patients in Nagaland \& immune reconstitution after treatment. Indian J Med Res 2009, 129:333-334.

23. Saikia L, Nath R, Hazarika D, Mahanta J: Atypical cutaneous lesions of Penicillium marneffei infection as a manifestation of the immune reconstitution inflammatory syndrome after highly active antiretroviral therapy. Indian J Dermatol Venereol Leprol 2010, 76:45-48,

24. Ho A, Shankland GS, Seaton RA: Penicillium marneffei infection presenting as an immune reconstitution inflammatory syndrome in an HIV patient. Int J STD AIDS 2010, 21:780-782

25. Jayanetra P, Nitiyanant P, Ajello L, Padhye AA, Lolekha S, Atichartakarn V, et al: Penicilliosis marneffei in Thailand: report of five human cases. AmJTrop Med Hyg 1984, 33:637-644.

26. Louthrenoo W, Thamprasert $\mathrm{K}$, Sirisanthana T: Osteoarticular penicilliosis marneffei. A report of eight cases and review of the literature. $\mathrm{Br} J$ Rheumatol 1994, 33:1145-1150.

27. Chan YF, Woo KC: Penicillium marneffei osteomyelitis. J Bone Joint Surg Br 1990, 72:500-503.

28. Drouhet E: Penicilliosis due to Penicillium marneffei: a new emerging systemic mycosis in AIDS patients travelling or living in Southeast Asia. Review 44 cases reported in HIV infected patients during the last 5 years compared to 44 cases of non AIDS patients reported over 20 years. J Mycol Med 1993, 4:195-224.

29. Vanittanakom N, Cooper CR Jr, Fisher MC, Sirisanthana T: Penicillium marneffei infection and recent advances in the epidemiology and molecular biology aspects. Clin Microbiol Rev 2006, 19:95-110.

30. Sirisanthana T, Supparatpinyo K, Perriens J, Nelson KE: Amphotericin B and itraconazole for treatment of disseminated Penicillium marneffei infection in human immunodeficiency virus-infected patients. Clin Infect Dis 1998, 26:1107-1110.

31. Chaiwarith $R$, Charoenyos $N$, Sirisanthana $T$, Supparatpinyo $K$ : Discontinuation of secondary prophylaxis against penicilliosis marneffei in AIDS patients after HAART. AIDS 2007, 21:365-367.

\section{Pre-publication history}

The pre-publication history for this paper can be accessed here: http://www.biomedcentral.com/1471-2334/12/28/prepub

doi:10.1186/1471-2334-12-28

Cite this article as: Sudjaritruk et al.: Immune reconstitution inflammatory syndrome from Penicillium marneffei in an HIV-infected child: a case report and review of literature. BMC Infectious Diseases 2012 12:28. 